\title{
KEPALA MADRASAH, SUPERVISI AKADEMIK DAN KINERJA GURU (Kasus di Madrasah Ibtidaiyah Sirajul Ulum Jatiurip Krejengan Probolinggo)
}

\author{
Abdul Hamid \\ Institut Ilmu Keislaman Zainul Hasan Genggong Probolinggo \\ abdulhamid198024@gmail.com \\ Mohamad Ahyar Ma'arif \\ Institut Ilmu Keislaman Zainul Hasan Genggong Probolinggo \\ ahyarqotrun19@gmail.com
}

\begin{abstract}
Abstrak
Dalam proses belajar mengajar peran supervisi kepala madrasah memiliki peran strategis dalam meningkatkan mutu pendidikan, di mana para guru didalam melaksanakan tugasnya merupakan ujung tombak dalam mensukseskan tujuan pendidikan nasional. Di dalam pelaksanaan proses belaajar mengajar para guru seringkali mendapat kesulitan,dan kesulitan itu akan terjadi kemandegan dan kegagalan sekaligus berdampak pada mutu pendidikan, peran supervisi atau supervisor memiliki peran strategis dalam memberikan layanan terhadap guru yang mendapatkan kesulitan atau terjadi penurunan dalam kompetensinya. Tulisan ini berfokus pada kepemimpinan kepala madrasah dalam peningkatan kinerja. Tulisan ini menggunakan metode penelitian kualitatif. Data-data yang sudah didapatkan kemudian dianalisa dengan menggunakan analisis data deskriptif. Kepemimpinan kepala madrasah dalam peningkatan kinerja guru menggunakan dua teknik yakni supervisi akademik berbasis pada individu dan kelompok. Pelaksanaan supervisi akademik teknik individu untuk meningkatkan kinerja guru di Madrasah Ibtidaiyah Sirajul Ulum Jatiurip Krejengan Probolinggo yaitu menggunakan teknik orientasi bagi guru baru, classroom observation dan individual converence, sedangkan pelaksanaan supervisi akademik teknik kelompok untuk meningkatkan kinerja guru di Madrasah Ibtidaiyah Jatiurip Krejengan
\end{abstract}


Probolinggo yaitu menggunakan teknik rapat dewan guru, workshop/ lokakarya, bacaan terpimpin, buletin board dan karyawisata.

Kata Kunci: kepala madrasah, supervisi akademik, kinerja guru, madrasah ibtidaiyah

\begin{abstract}
In the teaching and learning process, the supervisory role of madrasah headmaster comprises a strategic role in improving educational quality, while the teachers in doing their tasks are seen as the lead in the efforts of achieving national education goals. In the implementation of teaching and learning process, most of the time teachers experience difficulties in which it causes stagnation and failure in improving as well as directly affecting the quality of the education itself. The role of supervision, or supervisor, possess a strategic role in providing services to teachers who experience difficulties or those who suffer declining competence. This paper focuses on the performance improvement of the leadership of the headmaster at madrasah. This paper used qualitative research methods. The data that has been obtained is analyzed by using descriptive data analysis. The leadership of Head master at Madrasah in improving teacher's performance is done by using academic supervision techniques based on individuals and groups. The implementation of academic supervision technique within individual in improving teacher's performance at Madrasah Ibtidaiyah (Islamic Primary School) Sirajul Ulum Jatiurip Krejengan Probolinggo is carried out by using orientation techniques for new teachers, classroom observations and individual conversions. Meanwhile, the implementation of academic supervision techniques within groups in improving teacher's performance in Madrasah Ibtidaiyah Sirajul Ulum Jatiurip Krejengan Probolinggo is carried out by using teacher council meetings technique, workshops, guided reading, bulletin boards and field trips.
\end{abstract}

Keywords: the headmaster of madrasah, academic supervision, teacher's performance, Islamic primary school

\title{
Pendahuluan
}

Esensi sebuah lembaga pendidikan formal adalah proses pembelajaran. Tidak ada kualitas pendidikan formal tanpa kualitas pembelajaran. Berbagai upaya peningkatan mutu pendidikan formal dapat dianggap kurang berguna bilamana belum menyentuh perbaikan proses pembelajaran. Oleh karena itu, dalam rangka peningkatan kualitas pendidikan formal, Pemerintah, dalam hal ini Kementerian Pendidikan dan Kebudayaan, mengembangkan 
berbagai program yang diharapkan dapat meningkatkan kualitas pembelajaran.

Fakta umum telah menunjukkan bahwa dalam mengelola madrasah diperlukan suatu rencana yang terinci, sehingga tidak terjadi pelaksanaan yang tumpang tindih, kurang koordinasi, komunikasi yang kurang interaktif, kurang motivasi, tidak transparan, kurang teliti, dan kurang dipahami didasarkan atas tugas dan fungsi organisasi. Kurang terprogramnya perencanaan madrasah menjadikan prestasi kerja yang dicapai oleh madrasah tidak maksimal. ${ }^{1}$

Di antara keseluruhan komponen dalam pembelajaran, guru merupakan komponen organik yang sangat menentukan. Tidak ada kualitas pembelajaran tanpa kualitas guru. Apapun yang telah dilakukan oleh Pemerintah, peningkatan kualitas pembelajaran tidak mungkin terwujud tanpa kualitas kinerja guru, sehingga peningkatan kualitas pembelajaran juga tidak mungkin tercapai tanpa adanya peningkatan kualitas para guru. "Guru merupakan sumber daya manusia yang sangat menentukan keberhasilan pembelajaran. Guru merupakan unsur pendidikan yang sangat dekat hubungannya dengan anak didik dalam upaya pendidikan sehari-hari di madrasah dan banyak menentukan keberhasilan anak didik dalam mencapai tujuan."

Begitu sangat strategisnya kedudukan guru sebagai tenaga profesional, Undang-Undang Republik Indonesia Nomor 14 Tahun 2005 tentang Guru dan Dosen, tepatnya Bab III Pasal 7, menegaskan bahwa profesi guru merupakan bidang pekerjaan khusus yang dilaksanakan berdasarkan prinsip sebagai berikut:

(a) memiliki bakat, minat, panggilan jiwa, dan idealisme; (b) memiliki komitmen untuk meningkatkan mutu pendidikan, keimanan, ketakwaan, dan akhlak mulia (c) memiliki kualifikasi akademik dan latar belakang pendidikan sesuai dengan bidang tugas; (d) memiliki kompetensi yang diperlukan sesuai dengan bidang tugas; (e) memiliki tanggung jawab atas pelaksanaan tugas keprofesionalan; (f)

1 Departemen Pendidikan Nasional, Pengolahan dan Analisis Data Penelitian, (Jakarta: Direktorat Jenderal Peningkatan Mutu Pendidik dan Tenaga Kependidikan, 2008) 1.

2 Departemen Pendidikan Nasional, Supervisi Akademik dalam Peningkatan Profesionalisme Guru, (Jakarta: Direktorat Jenderal Peningkatan Mutu Pendidik dan Tenaga Kependidikan, 2007) 1. 
memperoleh penghasilan yang ditentukan sesuai dengan prestasi kerja; (g) memiliki kesempatan untuk mengembangkan keprofesionalan secara berkelanjutan dengan belajar sepanjang hayat; (h) memiliki jaminan perlindungan hukum dalam melaksanakan tugas keprofesionalan; dan (i) memiliki organisasi profesi yang mempunyai kewenangan mengatur hal-hal yang berkaitan dengan tugas keprofesionalan guru. ${ }^{3}$

Selanjutnya, di dalam bab yang sama, pasal 7 ayat (2) juga diamanatkan bahwa pemberdayaan profesi guru diselenggarakan melalui pengembangan diri yang dilakukan secara demokratis, berkeadilan, tidak diskriminatif, dan berkelanjutan dengan menjunjung tinggi hak asasi manusia, nilai keagamaan, nilai kultural, kemajemukan bangsa, dan kode etik profesi. ${ }^{4}$

Salah satu program yang dapat diselenggarakan dalam rangka pemberdayaan guru adalah supervisi akademik, yaitu serangkaian kegiatan membantu guru mengembangkan kemampuannya mengelola proses pembelajaran demi pencapaian tujuan akademik. Supervisi akademik merujpakan upaya membantu guru-guru mengembangkan kemampuannya mencapai tujuan akademik. Dengan demikian, berarti, esensial supervisi akademik adalah membantu guru mengembangkan kemampuan profesionalismenya.

Mengembangkan kemampuan dalam konteks ini janganlah ditafsirkan secara sempit, semata-mata ditekankan pada peningkatan pengetahuan dan keterampilan mengajar guru, melainkan juga pada peningkatan komitmen (commitmen) atau kemauan (willingness) atau motivasi (motivation) guru, sebab dengan meningkatkan kemampuan dan motivasi kerja guru, kualitas akademik akan meningkat.

Di dalam Peraturan Menteri Pendidikan Nasional (Permendiknas) Nomor 13 Tahun 2007 tentang Standar Kepala Sekolah ditegaskan bahwa salah satu kompetensi yang harus dimiliki seorang kepala madrasah adalah kompetensi supervisi. Merujuk kepada Permendiknas tersebut, seorang kepala madrasah

\footnotetext{
${ }^{3}$ Undang-Undang Nomor 14 Tahun 2005 tentang Guru dan Dosen, Pasal 7 ayat (1). ayat (2).

${ }^{4}$ Undang-Undang Nomor 14 Tahun 2005 tentang Guru dan Dosen, Pasal 7
} 
harus kompeten dalam melakukan supervisi akademik terhadap guru-guru yang dipimpinnya. Dalam rangka itu seorang guru yang berkeinginan menjadi kepala madrasah perlu mengikuti program pendidikan dan pelatihan supervisi akademik dalam peningkatan profesionalisme guru.

Ditinjau secara objektif, Madrasah Ibtidaiyah Sirajul Ulum yang ada di Kecamatan Krejengan Kabupaten Probolinggo (selanjutnya disebut MI Sirajul Ulum), merupakan lembaga pendidikan Islam yang menjadi contoh lembaga pendidikan dasar se Kecamatan Krejengan. Hal ini didukung dengan beberapa indikator secara internal, yakni: kepemimpinan kepala madrasah yang terbuka dan demokratis, kedisiplinan dan partisipasi guru secara penuh, keaktifan siswa yang dikembangkan, dan didukung dengan sarana dan prasarana fisik (bangunan madrasah dan lainnya) yang terus ditingkatkan, serta kegiatan-kegiatan ekstrakurikuler madrasah bagi para siswa yang produktif.

Dalam hal ini dapat diketahui pula upaya-upaya kepala madrasah dalam meningkatkan kualitas dan mutu pendidikan di lambaga yang dipimpinnya, penulis juga dapat sepintas mengidentifikasi adanya hubungan baik pihak madrasah dan masyarakat sekitar madrasah.

Mengingat peran sentral kepala madrasah dalam mencapai tujuan pendidikan di madrasah, maka akan sangat bermanfaat sekali untuk mengetahui kinerja kepemimpinan kepala madrasah. Itulah yang mendorong dilakukannya kajian ini.

\section{Pembahasan}

\section{Supervisi Akademik dengan Teknik Individu}

Berdasarkan hasil observasi dan wawancara ditemukan data bahwa pelaksanaan supervisi yang dilakukan oleh kepala madrasah dalam melaksanakan kunjungan kelas melakukan, antara lain, merencanakan kunjungan kelas. Sebelum menrencanakan kunjungan kelas kepala madrasah terlebih dahulu memberi tahu kepada guru terkait. Proses pelaksanaan kunjungan kelas ini memang dilaksanakan bertahap, artinya tidak semua guru dikunjungi dalam satu waktu. Karena keterbatasan waktu dari kepala madrasah.

Pernyataan bahwa teknik kunjungan kelas bukan berarti bahwa guru yang bersangkutan dinilai kurang dalam menjalankan tugasnya selaku pendidik. Akan tetapi, dengan adanya kunjungan 
kelas ini, kepala madrasah mengetahui sejauh mana guru yang bersangkutan mengajar. Dari situlah kemudian akan menghasilkan kesimpulan, apakah guru ini dinilai kurang atau tidak dalam proses belajar mengajarnya.

Supervisi yang dilakukan oleh kepala madrasah ini merupakan pengawasan dan pengendalian kinerja para guru yang bertujuan untuk membantu guru dalam permasalahan proses belajar mengajar di kelas dan sebagai kontrol terhadap para guru dalam proses belajar dan mengajar agar dapat terlaksana secara terarah.

Hal ini sesuai dengan pendapat Arikunto dan Yuliana yang menyatakan bahwa supervisi akademik adalah supervisi yang menitik beratkan pengamatan pada masalah akademik, yaitu yang langsung berkaitan dengan lingkup kegiatan pembelajaran pada waktu siswa sedang dalam proses belajar. ${ }^{5}$ Adapun tujuan supervisi akademik adalah memperkembangkan situasi belajar dan mengajar yang lebih baik. Usaha perbaikan belajar dan mengajar ditujukan kepada pencapaian tujuan akhir dari pendidikan yaitu pembentukan pribadi anak secara maksimal. ${ }^{6}$

Berdasarkan hasil analisis di atas, supervisi akademik yang dilakukan oleh kepala madrasah tidak lain adalah untuk meningkatkan kualitas kinerja guru dan untuk memperbaiki proses belajar mengajar. Pelaksanaan supervisi akademik dengan teknik individu oleh kepala madrasah meliputi orientasi bagi guru baru, observasi kelas, dan intervisitasi.

\section{Orientasi bagi Guru Baru}

Pelaksanaan teknik orientasi guru baru di MI Sirajul Ulum dilaksanakan dengan cara memperkenalkan guru baru itu kepada rekan sejawatnya, menunjukkan situasi lingkungan fisik maupun fasilitas lain, memperkenalkan guru tersebut kepada muridmuridnya. Hal ini sejalan dengan pandangan Indrafachrudi bahwa guru baru juga perlu mendapatkan bimbingan dan penjelasan yang baik tentang keadaan madrasah, tugas dan masalah yang mungkin akan dihadapinya. Dengan begitu, guru-guru harus dapat merasakan bahwa mereka juga anggota warga madrasah tersebut.

5 Suharsimi Arikunto dan Lia Yuliana, Manajemen Pendidikan. (Yogyakarta: Aditya Media, 2009) 375.

${ }^{6}$ Binti Maunah, Supervisi Pendidikan Islam Teori dan Praktik, (Yogyakarta: Teras, 2009) 26. 
Hal ini dimaksudkan untuk mememperoleh hasil pembelajaran yang efektif.7

Selain itu, orientasi bagi guru baru ini dimaksudkan agar para guru baru tersebut dapat dengan mudah mengenal dan menyesuaikan diri dengan lingkungan dengan situasi baru dimana ia bekerja. Daryanto menyebutkan program orientasi itu meliputi hal-hal sebagai berikut: ${ }^{8}$

1. Memperkenalkan guru baru itu kepada rekan sejawatnya.

2. Menunjukkan situasi lingkungan fisik maupun fasilitas lain.

3. Memperkenalkan guru tersebut kepada murid-muridnya.

Pelaksanaan supervisi pendidikan dengan teknik orientasi bagi guru baru dilaksanakan dengan cara memperkenalkan guru baru itu kepada rekan sejawatnya, menunjukkan situasi lingkungan fisik maupun fasilitas lain, memperkenalkan guru tersebut kepada murid-muridnya agar tujuan untuk meningkatkan efektifitas dan efisiensi belajar mengajar yang dilaksanakan oleh guru di madrasah dapat tercapai dengan baik karena dengan demikian guru merasa ikut memiliki lingkungan seisinya tempat ia beraktivitas.

Uraian di atas menunjukkan bahwa supervisi yang diorientasikan pada guru baru tersebut merupakan upaya yang dilakukan oleh kepala madrasah untuk membantu para guru baru dalam melakukan penyesuaian dan pengenalan terhadap lingkungan serta kondisi madrasah di mana mereka juga merupakan anggota atau warga dari madrasah tersebut. Hal ini diharapkan dapat menciptakan situasi belajar mengajar yang efektif dan efisien sesuai dengan tujuan pembelajaran yang ditetapkan.

\section{Observasi Kelas}

Pelaksanaan observasi kelas diperlukan kejelasan tujuan yang hendak dicapai, data apa yang perlu direkam agar supaya observasi itu dapat mencapai keberhasilan yang diinginkan. Di MI Sirajul Ulum melakukan observasi kegiatan proses belajar mengajar walaupun hanya di luar kelas dan dilakukan tanpa memberitahukan jadwal kunjungan, serta mengadakan percakapan pribadi dengan guru yang bersangkutan tentang proses pembelajaran yang dilaksanakan.

\footnotetext{
${ }^{7}$ Soekarto Indrafachrudi, Mengantar Bagaimana Memimpin Sekolah Yang Baik, (Jakarta: Ghalia Indonesia, 1993) 73.

${ }^{8}$ Daryanto, Administrasi Pendidikan, (Jakarta: Rineka Cipta, 2001) 192.
} 
Sebagaimana dikatakan Daryanto, yang ditemukan dalam kunjungan ini adalah mempelajari sifat dan kualitas cara belajar anak dan bagaimana guru membimbing peserta didiknya. Adapun fungsi dari kunjungan kelas ini adalah sebagai alat untuk meningkatkan cara belajar mengajar. ${ }^{9}$ Kunjungan kelas ini juga membantu pertumbuhan profesional guru maupun supervisor, karena memberi kesempatan untuk meneliti terhadap kegiatan belajar mengajar, untuk meningkatkan kualitas pendidikan.

Dengan demikian dapat dikemukakan bahwa pelaksaanaan teknik supervisi secara individu degan cara mengobservasi kelas walaupun dilaksanakan dalam waktu yang tidak diprogramkan, sudah memenuhi syarat sebagai bahan analisa kegiatan yang pada akhirnya ditentukan solusi terhadap permasalahan yang menjadi kendala dalam memperoleh efektifitas belajar di madrasah.

\section{Intervisitasi}

Kegiatan ini dimaksudkan untuk menolong guru-guru yang mengalami masalah atau kesulitan-kesulitan mengajar, sebab dengan melihat pengalaman dengan sesama guru maka mereka dapat belajar atau bertukar pendapat untuk mencari solusi atas permasalahan atau kesulitan yang sedang dihadapinya.

Daryanto mengemukakan bahwa pelaksanaan kegiatan intervisitasi dimaksudkan agar guru dapat belajar dari orang lain, di antaranya dia dapat melihat contoh-contoh atau praktik mengajar yang dilakukan oleh guru lain, ingin mengetahui metode-metode baru yang diterapkan dan hal-hal baru lainnya. Dengan demikian, tidak menutup kemungkinan bagi seorang guru untuk belajar dari pengalam orang lain dalam melaksanakan proses pembelajaran. ${ }^{10}$

Kegiatan intervisitasi itu dapat membantu guru yang mempunyai kesulitan dalam mengajarnya sebab ada kemungkinan mereka mempunyai pengalaman yang berbeda atas permasalahan yang berbeda pula sehingga akan dapat meningkatkan profesionalitas dalam melaksanakan proses belajar mengajar di kelas atau madrasah masing-masing.

\section{Supervisi Akademik dengan Teknik Kelompok}

Teknik-teknik supervisi akademik yang digunakan Kepala MI Sirojul Ulum secara umum mempunyai tujuan untuk membantu

9Daryanto, Administrasi Pendidikan, 192.

${ }^{10}$ Daryanto, Administrasi Pendidikan, 196. 
memecahkan permasalahan maupun kesulitan yang dihadapi seorang guru baik dari guru itu sendiri maupun dari peserta didik yang merupakan komponen terciptanya proses pembelajaran guna meningkatkan kinerja guru yang memerlukan bimbingan maupun koordinasi yang baik dari supervisor.

Pembinaan dalam pengelolaan madrasah yang berhubungan dengan penyusunan program pengelolaan yang aktif secara efektif dan menunjang pelaksanaan mengajar. Adapun teknik supervisi akademik yang digunakan oleh kepala madrasah adalah teknik supervisi akademik secara individual dan teknik supervisi akademik secara kelompok. Adanya teknik supervisi akademik secara individual dan kelompok yang sesuai dengan fungsi pengawasan diharapkan dapat meningkatkan kinerja guru MI Sirajul Ulum.

Uraian di atas mengungkapkan bahwa Kepala MI Sirajul Ulum pada prinsipnya telah menerapkan teknik supervisi yang tepat untuk meningkatkan kinerja guru meskipun proses supervisi akademik yang dilakukan belum berjalan secara optimal. Untuk itu, dibutuhkan perbaikan dan evaluasi dari kepala madrasah dalam hal pelaksanaan supervisi akademik di MI Sirajul Ulum. Adapun pelaksanaan supervisi akademik dengan teknik kelompok oleh Kepala MI Sirajul Ulum meliputi: rapat dewan guru, workshop, bacaan terpimpin, bulettin board, dan karyawisata.

\section{Rapat Dewan Guru}

Rapat dewan guru dilaksanakan baik itu yang bersifat administratif maupun supervisi merupakan suatu upaya atau teknik untuk membantu kesulitan maupun permasalahan yang dihadapi oleh guru sebagai pemeran utama pada upaya mencapai efektivitas dan efisiensi poses pembelajaran disuatu lembaga pendidikan. Hal ini sejalan dengan pendapat Sukadi bahwa Rapat dewan guru ini perlu dikembangkan dengan melibatkan secara bersama-sama antara guru mata pelajaran sejenis, kepala madrasah dan pengawas madrasah dalam suatu forum. ${ }^{11}$

Uraian di atas menunjukkan bahwa kegiatan rapat dewan guru di MI Sirajul Ulum dilaksanakan dalam rangka meningkatkan mutu pembelajaran walaupun tidak semua dewan guru aktif mengikuti kegiatan tersebut dan dilaksanakan secara non formal, kegiatan ini ditekankan terutama pada guru sebagai pemeran

\footnotetext{
11 Sukadi, Guru Powerfull Guru Masa Depan, (Bandung: Kholbu, 2001)
} 362-363. 
utama dalam memberikan pengajaran langsung pada peserta didik dan diharapkan mampu mendorong atau memotivasi para peserta didik untuk aktif dan apresiatif.

\section{Workshop/Lokakarya}

Kegiatan ini dilaksanakan di MI Sirajul Ulum untuk memberi kesempatan kepada para peserta untuk memikirkan masalah mereka, dibantu oleh nara sumber sambil berusaha memecahkannya yang dilaksanakan setiap jangka waktu akhir semester. Hal ini sejalan dengan teori yang meyatakan bahwa workshop merupakan salah satu teknik supervisi yang memberi kesempatan kepada para peserta untuk memikirkan masalah mereka, dibantu oleh nara sumber atau resource people sambil berusaha memecahkannya. Dengan diselenggarakannya workshop, maka diharapkan guru mempunyai alternatif-alternatif maupun kreatifitas yang mengarah pada efektifitas dan efisiensi dalam proses pembelajaran di madrasah. ${ }^{12}$

Dengan demikian, kegiatan workshop atau lokakarya, maka seorang guru atau peserta workshop mempunyai kesempatan untuk mencari teknik dan memberikan yang terbaik dalam melaksanakan proses pembelajaran di kelas dengan stimulus dari pakar yang membantu mereka dalam membahas permasalahan atau kesulitan yang mereka hadapi.

\section{Bacaan Terpimpin}

Profesionalitas seorang guru tercermin antara lain dalam kemauan dan kemampuannya untuk belajar secara terus dalam rangka meningkatkan dan memperbaiki tugas utamanya yaitu mengajar. Alhasil, guru MI Sirajul Ulum berusaha menyediakan berbagai macam koleksi atau referensi bacaan yang terkait dengan pembelajaran untuk memperkaya wawasan yang dimiliki guru dalam memnberikan pengajaran di kelas.

Terkait hal ini, Daryanto mengatakan bahwa upaya meningkatkan kualitas profesi yang dimiliki oleh guru yaitu dengan cara menyediakan buku-buku atau sumber bahan bacaan sesuai dengan bidang ilmu yang dikembangkan, karena buku merupakan salah satu sumber pengetahuan yang utama khususnya dalam meningkatkan kualitas profesi mengajar. ${ }^{13}$

\footnotetext{
${ }^{12}$ Indrafachrudi, Mengantar Bagaimana Memimpin Sekolah Yang Baik, 81

13 Daryanto, Administrasi Pendidikan , 200.
} 
Dengan demikian, dalam memperluas wawasan dan meningkatkan kualitas pembelajaran yang dilaksanakan, maka pemberian bahan bacaan yang sesuai dengan tugas profesi yang dimilikinya akan dapat menghasilkan suasana belajar mengajar yang lebih efektif dan menyenangkan serta memiliki nilai wawasan yang luas.

\section{Bulettin Board}

Kepala madrasah selaku supervisor mengeluarkan suatu bentuk tulisan yang ditempelkan di mading yang digunakan sebagai alat untuk membantu guru-guru dalam memperbaiki proses belajar mengajar, seperti: informasi mengenai metode-metode mengajar yang baru dan baik, adanya sistem penawaran sistem baru dalam pendidikan, pernyataan singkat kepala madrasah mengenai program pendidikan dan lain-lain.

Melalui bulletin board, supervisor dapat membantu guru menambah pengetahuan, pengalaman, serta menimbulkan minat mereka untuk mengadakan penyelidikan selanjutnya demi perbaikan mutu pekerjaan mereka yaitu sebagai pendidik. ${ }^{14} \mathrm{Hal}$ ini membuktikan bahwa seorang guru memerlukan informasi tentang pendidikan baik dari penggunaan metode maupun sistem pembelajaran yang baik dan tepat dalam perbaikan dan pengembangan proses pembelajaran di madrasah untuk mencapai tujuan pembelajaran semaksimal mungkin.

\section{Karyawisata}

MI Sirajul Ulum menerapkan kurikulum pembelajaran yang disesuaikan dengan kebutuhan siswa dan masyarakat sekitarnya, sehingga dengan metode pembelajaran yang digunakan, guru harus mampu mengkaitkan materi pembelajaran dengan kondisi yang berada di sekitar madrasah tersebut. Teknik karyawisata menurut Indrafachrudi sangat penting kaitannya dengan pelaksanaan pendidikan, karena untuk mengetahui objek wisata yang ada, terutama yang berada dekat dengan lingkungan madrasah yang sangat erat hubungannya dengan kurikulum. ${ }^{15}$

Dengan demikian berdasarkan uraian di atas dapat dikemukakan bahwa dengan teknik karyawisata sangat diperlukan dalam penyusunan kurikulum pembelajaran maupun teknik

\footnotetext{
${ }^{14}$ Indrafachrudi, Mengantar Bagaimana Memimpin Sekolah Yang Baik, 83.

${ }^{15}$ Indrafachrudi, Mengantar Bagaimana Memimpin Sekolah Yang Baik, 80.
} 
pembelajaran yang dijadikan patokan dalam penyelengaran pembelajaran di madrasah, sebab suatu masyarakat atau lingkungan akan mengalami kemajuan berdasarkan ketepatgunaan dari penggunaan ilmu pengetahuan yang diperolehnya dari lembaga pendidikan yang ada.

\section{Simpulan}

Substansi dari pelaksanaan supervisi akademik yaitu penerapan prinsip supervisi kontinyu, obyektif, konstruktif, humanistik dan Kolaboratif, melaksanakan supervisi akademik yang berkelanjutan rencana jangka panjang, jangka menengah, pendek, melaksanakan supervisi akademik yang didasarkan pada kebutuhan dan masalah nyata yang dihadapi oleh guru, menempatkan pertumbuhan kompetensi guru dan peningkatan kualitas pembelajaran sebagai tujuan utama supervisi akademik, membangun hubungan dengan guru dan semua pihak yang terlibat dalam kegiatan supervisi yang terbuka, kesetiakawanan, dan informal yang berlandaskan pada sikap-sikap membantu,memahami, terbuka, jujur, ajeg, sabar, antusias, dan penuh humor, melaksanakan supervisi yang demokratis, melibatkan secara aktif, berbagi tanggung jawab pengembangan pembelajaran dengan guru dan pihak lain yang relevan, melaksanakan supervisi yang demokratis. Jika ini dilaksanakan dengan baik, maka program supervisi dikatakan yang ikut menentukan ketercapai program supervisi dan pada akhirnya mutu pendidikan meningkat.

Kepemimpinan kepala madrasah dalam peningkatan kinerja guru menggunakan dua model teknik supervisi yakni individu dan kelompok. Pertama pelaksanaan supervisi teknik individu untuk meningkatkan kinerja guru di Madrasah Ibtidaiyah Jatiurip Krejengan Probolinggo yaitu menggunakan teknik orientasi bagi guru baru, classroom observation dan individual converence sudah dilakukan namun dalam prakteknya masih belum berjalan secara optimal. Kedua pelaksanaan supervisi dengan teknik kelompok untuk meningkatkan kinerja guru di Madrasah Ibtidaiyah Jatiurip Krejengan Probolinggo menggunakan teknik rapat dewan guru, workshop/ lokakarya, bacaan terpimpin, buletin board dan karyawisata. 


\section{Referensi}

Arikunto, Suharsimi \& Lia Yuliana. Manajemen Pendidikan. Yogyakarta: Aditya Media, 2009.

Danim, Sudarwan. Otonomi Manajemen Sekolah. Bandung: Alfabeta, 2010.

Daryanto. Administrasi Pendidikan. Jakarta: Rineka Cipta, 2001.

Departemen Pendidikan Nasional. Pengolahan dan Analisis Data Penelitian. Jakarta: Direktorat Jenderal Peningkatan Mutu Pendidik dan Tenaga Kependidikan, 2008.

Departemen Pendidikan Nasional. Penilaian Kinerja Guru. Jakarta: Direktorat Jenderal Peningkatan Mutu Pendidik dan Tenaga Kependidikan, 2008.

Departemen Pendidikan Nasional. Supervisi Akademik dalam Peningkatan Profesionalisme Guru. Jakarta: Direktorat Jenderal Peningkatan Mutu Pendidik dan Tenaga Kependidikan, 2007.

Djamarah, Syaiful Bahri. Guru dan Anak Didik dalam Interaksi Edukatif. Jakarta: Rineka Cipta, 2000.

Indrafachrudi, Soekarto. Mengantar Bagaimana Memimpin Sekolah Yang Baik. Jakarta: Ghalia Indonesia, 1993.

Maunah, Binti. Supervisi Pendidikan Islam Teori dan Praktik. Yogyakarta: Teras, 2009.

Mulyasa. Menjadi Guru Profesional, Bandung: Remaja Rosdakarya, 2002.

Sukadi. Guru Powerfull Guru Masa Depan. Bandung: Kholbu, 2001.

Undang-Undang Nomor 14 Tahun 2005 tentang Guru dan Dosen

Usman, Moh. Uzer. Menajdi Guru Profesional. Bandung: Remaja Rosda Karya, 2003.

Wahjosumidjo. Kepemimpinan Kepala Sekolah. Jakarta: PT Raja Grafindo Persada, 2003. 